\title{
Delito de opinião ${ }^{(*)}$
}

\section{A. de Sampaio Doria}

Aqui estou, em nome de meus pares da velha Faculdade de S. Paulo, para vos trazer as expressões de sua solidariedade, na reparação, agravada pela demora, que acaba de ser feita aos professores Castro Rutbelo, Hermes Lima, Leonidas Rezende, e, por fim, Bilac Pinto. Como discordância da clamorosa injustiça, que os vitimou, essa Faculdade nos deu a todos, em sua irredutibilidade e serenidade, a lição da fé imperecível na Justiça, que cultua, esperandoos com suas cadeiras vagas.

Tambem, na Faculdade de São Paulo, três dos seus professores, titulares por concurso, foram, num só dia, arrebatados às suas catedras, pelo delito de pensar livremente. Ȧ parte quem vos fala, (para não falar de mim mesmo) as vítinıas do arbítrio que desfalcou aquela casa de tradição, de civismo e de amor à justiça, eram, como vós, professores eminentes, e cidadãos de probidade. Nada se articulára que os desabonasse, nem mesmo por omissão. Mas eram professores que, prezando a liberdade acima das mutações politicas, prosseguiam no ensino do direito, como lhes cumpria, pondo a nú as inliquidades, pregando a verdade jurídica, e condenando os erros, ainda que na lei. E o que, por uma espécie de fatalidade histórica, se respira insensivelmente na atmosfera, eletrizada e vibrante, daquela velha casa de ensino. 'Ali, jamais se descreu da justiça; ali, foi sempre

(*) Discurso proferido na sessão solene em que a Faculdade Nacional de Direito, da Universidade do Brasil, recebeu quatro professores, reintegrados em seus cargos, em maio de 1945. 
ardente o culto da pátria; ali, nunca se apagou o ideal da democracia e da liberdade, acima de tudo. Nêstes longos nnos de irresponsabilidade do poder nas urnas, a Faculdade de Direito de S. Paulo foi, entre nós, talvês, o mais impcnitente reduto de resistência democrática e liberal.

$\mathrm{E}$, aqui, porquê, srs. professores, reintegrados hoje no que vos pertence, tambem vos afastaram do ensino, que vos cabia, do direito á mocidade?

Explicitamente, por delito de opinião.

Mas, ainda haverá, onde a civilização não se reduza a progresso material, ainda haverá quem haja por crime pensar livremente?

0 gênio do mal parece, em verdade, não desertar nunca da terra. . A presunção de infalibilidade enfuna os individuos, quando lhes cae nas mãos o poder material ou espiritual. Parece que os desnorteia quase sempre a intolerância, com que exorcisam os dissidentes, para o aniquilamento de toda a opinião contrária á que tenham.

Mas, hoje, já não se compreende o princípio de infalibilidade no homem, seja sôbre o que fôr. Em ciência, as verdades, por mais singelas, dependem, para serem apanhadas, de dados sensoriais, que a inteligência interpreta. E a pobre inteligência do homem não logra perceber, em si mesmos, nem siquer os atributos das cousas, quanto mais a essência delas. Tudo o que nos é dado conhecer, todo o universo que concebemos, é, apenas, uma alucinação permanente do espírito. O cérebro humano não reflete as realidades, como espelho plano. Mas as transfigura, criando mundos que não existem, dentro dos quais nos agitamos, do berço ao túmulo, sem nos luzir siquer a esperança de poder, um dia, conhecer, em si mesmas, as realidades que nos cercam.

Porque, entẩo, a presunção de infalibilidade? E, mais, o monopólio da verdade? E, por cima, a intolerância que condena quem pense diferentemente, e só por isso? 
Lancemos, a êste respeito, os olhos pelos cimos da intolerância, na história da humanidade, e a cuja evocação, ainda hoje, o homem se enche de piedade, indignação e horror. Ouvi como a três dentre êles se refere Stuart Mill, a quem devemos, num opúsculo de cento e poucas páginas, o mais radiante luzeiro, que já foi, no mundo, acêso á inteligência do homem, sôbre a liberdade.

Evoquemos, como êle, nesta solenidade, três dêsses grandes desatinos da intolerância política e religiosa.

Primeiro, a condenação de Socrates. "Nunca é demais lembrar", diz Stuart Mill, "que houve outrora um homem chamado Socrates, entre o qual e as autoridades legais de seu tempo se deu memorável colisão. Nascido num século e pais exuberante em grandeza individual, a memória dêsse homem nos foi legada por aquêles que melhor o conheceram a êle e ao século em que viveu, como o homem mais virtuoso daquêles tempos". Não obstante, êsse homem superior, "cuja grandeza moral sobrevive aos tempos", foi condenado á morte por seus contemporâneos, pelo crime de impiedade e de imoralidade. Impiedade, por negar os deuses; e imoralitdade, por corromper, com suas doutrinas, a mocidade. "Destas acusações, continua Stuart Mill, o tribunal (toda razão há para o crêr) em consciencia o achou culpado; e condenou á pena de morte, como a um criminoso, o homem que, provavelmente, de todos quantos então existiam, era o que mais merecêra da humanidade".

Outro crime da cegueira política e religiosa, que envergonha, mais que todos, a vida do homem na terra, é o da tragédia do Calvário, há pouco mais de 19 séculos. "O homem que deixou, na memória de todos os que foram testemunhas de sua vida e de suas doutrinas, expõe Stuart MıL, tamanha impressão de sua grandeza moral, que 18 séculos subsequentes lhe têm prestado homenagens como ao próprio Onipotente, foi ignominiosamente condenado á morte". Condenado por blasfêmo, e perigoso á ordem pública e ao poder constituido. Erraria, porém, quem julgasse terem 
sido os homens daquele tempo piores "do que o são comumente os homens em todos os tempos". Segundo todas as aparências, "eram êles homens que possuiam no mais alto grau os sentimentos religiosos, morais e patrióticos de seu tempo e de sua nação". Os homens patriotas e religiosos de hoje, "se tivessem vivido naquele tempo e nascidos judeus, continua Stuart MuL, teriam procedido justamente como êles". "Os cristãos ortodóxos, que se sentem inclinados a pensar, que os apedrejadôres dos primeiros mártires, dando-lhes assim a morte, devem ter sido piores do que o são, devem lembrar-se de que um dêles foi São Paulo".

Agora, o terceiro caso, e êste de todos o mais expressivo, "se a impressão produzida pelo erro é medida pela sabedoria e virtude daquele que o tiver cometido" "Se jamais houve, aprecia Stuart MiLl, quem, nas alturas do poder, tivesse motivos para se julgar o melhor e o mais ilustre êntre os seus contemporâneos, êsse foi o imperadôr Marco Aurélio". Apesar de monárca absoluto, tudo fez por não se desviar intencionalmente da justiça, e, o que é de louvar, "conservou sempre o mais afável coração" Pois êste homem, acrescenta o Mestre, "melhor çristão em tudo, menos no sentido dogmático do mundo, do que qualquer dos soberanos ostensivamente cristãos, que de então até hoje têm reinado", se sentiu, como legisladôr, no dever indeclinável de ordenar a perseguição dos partidários de Cristo. Pareceu-lhe que, no deplorável estado a que decaíra a sociedade romana, só pela crença e veneração das divindades aceitas, poderia obstar a que se degenerasse ainda mais. Não lhe pareceu crível "a extranha história de um Deus crucificado", e, vendo que o culto da nova religião destruía os laços de coesão social da antiga, sem os substituir por equivalentes, teve por acertado que, para não se esfacelar de vês a sociedade a cujos destinos presidia, só lhe restava um caminho: perseguir os cristãos. ,Seria, porém, tão injusto quanto a êle, como falso quanto á verdade, julga Stuart Mill, negar que qualquer das causas alegáveis hoje, para punir o ensino anti-cristão, faltasse a Marco Aurélio, 
para punir, como puniu, a propagação do cristianismo. Nenhum cristão crê mais firmemente a falsidade do ateismo e sua tendênciia á destruição da sociedade, do que Marco Aurélio, quando acreditou nas mesmas cousas a respeito do cristianismo, êle que de todos os homens de seu tempo se poderia haver pelo mais capaz de o apreciar". A menos que os partidários de se punir a crença em deuses alheios, ou de tirar a professores suas càtedras por delito de opinião, "não se lisongeiem de ser mais sábios e melhores que Marco Aurélio, mais profundamente versados na sabedoria de seu tempo, de inteligência superior á dêle, mais incansável na investigação da verdade, ou de espírito mais concentrado na devoção para com ela, quando descoberta, a menos que assim não seja, prossegue Stuart Mill, que se abstenham daquela presunção de infalibilidade comum a si e ao povo, que o grande Antonino abraçou com tão infeliz resultado".

A paixão política não aprendeu, nem com tais exemplos, a conter-se: persevera em sua fâina, como, êntre vós, arrebatando a tribuna a professores eminentes, pelo crime de pensar livremente.

O caso aqui ainda se agravou com a semcerimónia do desrespeito a direitos adquiridos. Nos climas revolucionários, vem de todos os quadrantes o sopro diabólico de não haver direitos do indivíduo, contra os interesses da sociedade, ou do Estado.

Mas, senhores, a necessidade social mais alta, o interesse supremo do Estado, num povo policiado, é precisamente o respeito aos dïreitos adquiridos. Na constituição de 1891, a mais perfeita de quantas o mundo já viu, na substância e na fórma, e a que não se sabe porque não tornarmos, adaptando-a ás necessidades presentes, se vedava, assim aos Estados como á União, prescrever leis retroatívas. Era a consagração constitucional dos direitos adquiridos, como barreiras aos desvarios das paixões soberanas. A Constituição de 1934, inferior á de 1891 nas vigas mestras da Federação, e do governo republicano e presidencial, 
soube, ainda bem, manter o senso jurídico de respeito aos direitos adquiridos, ao ato jurídico perfeito e á cousa julgada.

Seria preciso realmente esvasiar-se a mente dos eternos principios do direito, para vir um povo, e ainda na esteira das ditaduras arrogantes, que trepudiavam no velho mundo, aplicar em nome de razões de Estado, a norma arrepiada e cega de desrespeito aos direitos, se contrários aos interesses do poder constituído, quando, em verdade bem verdadeira, o dever mais elementar do Estado é filar pela gola os que vivem a desrespeitá-los.

Permiti, agora, os senhores professores que ora tornam ao lar de sua predestinação, que outro professor, e êste com mais de quatro decádas de magistério, faça, nesta comemoração bendita, uma sugestão para toda a vida, á mocidade de minha pátria, aqui palpitante nos moços desta Faculdade.

Por certo, já lestes, ou ouvistes falar, de um eldorado de maravilhas, cuja existência se anuncia em terras distantes, por obra e graça de um regime, tão grato ao coração dos que sofrem. E o inimaginável da produção coletiva, planificada em quinquênios, sob a inspiração de gênios benfazejos, e garantida pela mão de aço de um chefe todo poderoso. Na conquista dos bens econômicos, ali o homem não explora o homem: todos trabalham para todos, e, por isto, as riquezas dão a todos a bemaventurança na glória de viver.

Tambem eu tenho ouvido falar nesta redenção paradisiáca, cujo sonho data não se sabe de quantos milênios. Nunca me esqueci, porém, de uma lição que aprendi desde cêdo. E a de que as riquezas são meio, e não o fim da vida. Só não convirá nisso o avarento, de quem se costuma dizer que, como o porco, só tem utilidade depois de morto. Trabalha-se para viver a coberto de misérias; mas nunca para negro de senzala, ou escravo do dinheiro. Em verdade, a fartura na vida material não exclue a nobreza na vida do espírito. Bem mesquinho seria o ideal da inde- 
pendência econômica, com o desprezo da liberdade. Lembraria o despropósito de quem, cançado de viajar de $3 .^{a}$ classe, se metesse num trem de luxo, na iminência de perecer num desastre, ou a sina inconsciente dos suinos que engordam à farta para o córte de amanhã.

Na organização do Estado, não há misturar duas cousas inconfundíveis: sua estruturação política, e a estruturação econômica da sociedade.

$\mathrm{Na}$ finalidade econômica, o Estado providencia, por todos os modos, para o extermínio ou atenuação da miséria; enseja, quanto pode, nivel satisfatório de vida a todos os que trabalham; não tolera a opressão do capital que folga, contra o trabalho que vegeta, espoliado; tudo faz, em suma, para dar, tambem em matéria econômica, a cada um o que é seu.

Mas, no objetivo político, cumpre ao Estado, acima de tudo, defender a pátria contra agressões estrangeiras, manter a ordem pública interna, e promover o bem comum. Uma constituição política é obra de imprudentes e exorbita da bôa técnica, se vai além da composição dos órgãos do Estado, das atribuições de cada um, e da definição dos direitos e garantias do homem.

No asseguramento dêstes direitos está a suprema razão da ordem pública. É para o respeito á personalidade do homem, que os homens compõem o aparelhamento do Estado. Nunca e nunca para o sacrifício dos direitos da personalidade, sejam quais fôrem as perspectivas de riquezas prometidas.

Mas, se, por um doloroso fadário, para a fartura de todos, é preciso ignorar a personalidade de cada um; se, para manter a ordem aparente, é preciso arruinar a ordem jurídica; se, para a justiça distributiva das riquezas, é preciso desdenhar os direitos do homem; então, não há outra saída, para quem quer que não tenha na alma, o azinhavre do avarento: é pôr, acima dos bens materiais, a dignidade da vida. 
Não duvideis, porém, meus caros amigos, da possibilidade de conciliar as oportunidades a todos, para irem até onde lhes permitirem as forças e a diligência que empreguem, com o respeito aos direitos do homem, proporcionando a todos a igualdade no exercício da liberdade.

Quando, pois, ouvirdes falar no milagre de um regime que assegure, com perfeição, a ordem nas ruas; de um regime de socialização integral dos instrumentos de produção, de um regime em que tenha sido banida, para sempre, a exploração capitalista; de um regime onde o ouro reluz á flôr da terra, e resalta das pedras para o bolso dos transeuntes, perguntai:

Mas o homem, nêste regime, se fôr preso sem motivo justo, tem para quem apelar? Mas o homem, nêste regime, se, por discordar das divindades aceitas, ou da ciência oficial, ou da política do governo, sumir-se em masmorras ignoradas, tem para quem recorrer? Mas o homem, nêste regime, se, por ter reinvidicado, na praça pública, melhoria de salário, desaparecer misteriosamente da circulação, tem como defender-se, para tornar aos braços dos seus?

Perguntai, indagai, verificai: há, nesta Canaan sonhada, garantias para os direitos do homem? Sempre que o individuo sofrer, ou se achar na iminencia de sofrer, "coação ou violencia, por ilegalidade, ou abuso de poder", darse-á o habeas-corpus?

Se sim, o regime tem préstimo, e dignifica o povo que o haja adotado.

Se, não, o regime é o opróbrio do homem, e, pois, não vale nada.

Aceitai, senhores professores, no que acabo de dizer a vossos discípulos, as saudações mais reverentes da Faculdade de Direito de São Paulo. 